\title{
DAMPAK BERPIKIR POSITIF BAGI ANAK BERKEBUTUHAN KHUSUS TUNANETRA DI YAKETUNIS YOGYAKARTA
}

\author{
Marsha Delvytamara \\ Fakultas Psikologi \\ Universitas Ahmad Dahlan \\ marshadelvytamara1998@gmail.com
}

\begin{abstract}
Abstrak
Anak penyandang tunanetra merupakan anak berkebutuhan khusus. Dapat dikatakan sebagai tunanetra apabila individu mengalami suatu hal yaitu kondisi penglihatannya tidak berfungsi sebagaimana mestinya. Dengan keterbatasan yang dimiliki individu penyandang tunanetra mereka mempunyai semangat berpikir positif, karena dengan berpikir positif mereka akan mudah untuk menyelesaikan suatu masalah dan dapat mengurangi stres pada dirinya sendiri. Selain itu manfaat yang diperoleh para penyandang tunanetra dengan berpikir positif yaitu mempunyai rasa penerimaan diri yang tinggi terhadap keterbatasan yang mereka miliki.
\end{abstract}

Kata kunci: berpikir positif, anak berkebutuhan khusus tunanetra

\section{PENDAHULUAN}

Menurut Efendi (2006), anak berkebutuhan khusus merupakan anak yang mempunyai kelainan dari keadaan rata-rata anak yang normal pada umumnya dari segi fisik, mental, dan karekteristik sosialnya. Menurut Heward dan Orlansky (1992) anak berkebutuhan khusus adalah anak-anak yang memiliki keadaan fisik atau kemampuan belajar yang berbeda dari anak normal, baik diatas atau dibawah, yang tidak selalu menunjukkan ketidakmampuan fisik, mental, atau emosi, sehingga membutuhkan program individual dalam pendidikan khusus. Menurut Ganda Sumekar (2009) anak berkebutuhan khusus adalah anak-anak yang mengalami penyimpangan atau kelainan dalam segi fisik, mental, emosi dan sosial, atau dari gabungan hal-hal tersebut sehingga mereka memerlukan pelayanan pendidikan yang khusus yang disesuaikan dengan penyimpangan atau kelainan mereka.

Salah satu klasifikasi anak berkebutuhan khusus adalah tunanetra (Suparno, 2007). Menurut Sasranigrat (1984) anak tunanetra adalah anak yang mengalami 
sesuatu hal sehingga kondisi penglihatannya tidak berfungsi sebagaimana mestinya. Menurut Soemantri (2007), penyandang tunanetra adalah orang yang tidak bisa melihat dan yang mampu melihat tetapi terbatas sekali serta kurang dapat memanfaatkan untuk kepentingan hidup sehari-hari, terutama dalam belajar. Menurut (Somantri, 2006), penyandang tunanetra yaitu orang yang indra penglihatannya mengalami gangguan atau kerusakan sehingga indra penglihatannya tidak dapat berfungsi secara normal. Dalam kondisi tidak mampu melihat lagi, beberapa individu beranggapan bahwa dirinya lemah sehingga membuatnya mengubah tatanan hidup yang ada pada dirinya, namun hal tersebut tidak berlaku bagi individu yang selalu berpikir positif. Tujuan dari penulis adalah ingin mengetahui dampak berpikir positif bagi anak tunanetra dan sumber-sumber berpikir positif bagi anak tunanetra.

\section{PEMBAHASAN}

Menurut Albrecht (1980), berpikir positif adalah memfokuskan perhatian pada hal-hal positif serta menggunakan bahasa positif dalam mengekspresikan pikiran. Menurut Peale (1996), berpikir positif adalah penerapan langsung dalam hal agama untuk mengatasi kekalahan dan digunakan untuk menciptakan suasana yang menguntungkan dalam perkembangan yang positif. Menurut Peale (1977), berpikir positif adalah memandang segala hal dengan positif, karena dengan berpikir positif dalam suatu permasalahan pasti terdapat pemecahan dan pemecahannya diperoleh dalam intelektual yang sehat. Menurut Cahyono (2011), pikiran positif adalah pikiran yang dapat membangun dan memperkuat kepribadian karakter individu.

Ciri-ciri individu yang berpikir positif menurut Nald (2005), yaitu: pikirannya terbuka untuk menerima saran dan ide sehingga melihat masalah sebagai suatu tantangan dengan menghilangkan pikiran negatif mengenai berita yang belum pasti kebenarannya, tidak membuat alasan tetapi langsung membuat tindakan, memperhatikan citra dirinya, menggunakan bahasa verbal dan non verbal yang positif, menikmati hidup dengan mensyukuri hal yang dimilikinya.

Dampak berpikir positif menurut Albrecht (1980), adalah membuat individu dapat meningkatkan kemampuan dan akan menghasilkan kesan yang positif. Dengan 
berpikir positif individu memiliki penyesuaian diri yang lebih baik dibanding orang yang berpikir negatif sehingga dapat menurunkan stres individu (Taylor, 1995). Menurut Tobing (2006) manfaat berpikir positif bagi individu adalah membuat individu mampu menerima keadaannya dengan besar hati, sehingga dapat mencapai hidup yang lebih baik. Berpikir positif mampu meningkatkan penerimaan diri individu Tentama (2010; 2014). Lebih lanjut lagi, Tentama (2012) menambahkan bahwa berpikir positif membuat individu mampu memusatkan perhatian pada hal-hal positif dari berbagai permasalahan yang dihadapinya. Dengan berpikir positif individu akan merasa tenang, rileks, dan dapat menyesuaikan dirinya untuk mengatasi masalah yang dihadapi.

Sumber dari berikir positif adalah harapan karena dengan harapan dapat membuat individu dapat termotivasi untuk berpikir yang positif sehingga, menghasilkan tujuan yang diinginkan (Snyder, 2002). Menurut Sulistiya (2005), sumber dari berpikir positif yaitu adanya sikap optimis menghadapi kehidupan dan menganggap diri sendiri berharga sebagai individu yang sederajad dengan orang lain. Sementara itu menurut Ibrahim (2009), sumber dari berpikir positif yaitu kekuatan, karena dengan kekuatan dapat membantu memberikan solusi. Selain itu kekuatan disebut juga sebagai sumber kebebasan karena dapat menjadikan individu terbebas dari penderitaan dan lingkungan pikiran negatif terhadap pengaruh fisiknya.

\section{KESIMPULAN}

Dampak dari berpikir positif pada anak berkebutuhan khusus penyandang tunanetra diyaketunis yaitu dapat meningkatkan kemampuan suatu individu menjadi lebih baik. Dengan berpikir positif individu lebih mempunyai penyesuaian diri yang baik dibandingkan dengan individu yang tidak berpikir positif. Hal tersebut, membuat suatu individu lebih menghargai apapun yang mereka miliki. Sedangkan sumbersumber yang sangat berperan dalam berpikir positif adalah adanya motivasi diri yang tertanam dalam suatu individu sehingga menimbulkan rasa optimis dalam diri individu. Selain itu kekuatan juga menjadi sumber penting dalam penerapan berpikir 
positif, sehingga menjadikan individu terbebas pada suatu penderitaan dan pikiran negatif. 


\section{DAFTAR PUSTAKA}

Albrecht, K. G. (1980). Brain power learn to improve your thinking skill. New Jersey: Prenctice-Hall.inc.

Cahyo, S. W. (2011). Think positive feel positive \& get positif life. Yogyakarta: Second Hope.

Efendi, M. (2006). Pengantar psikopedagogik anak berkelainan. Jakarta: Bumi Aksara.

Heward, W. \& Orlansky, M. (1992). Exceptional children. New York: Macmillan.

Nald, D. (2005). 10 Ciri orang orang berpikir positif. New York: Scott, Foresman and Company.

Peale, N. V. (1996). Berpikir positif. Jakarta: Binarupa Aksara.

Peale, N. V. (1997). Cara hidup dan berpikir positif: The ama ing result of positive thinking. Jakarta: Gunung Jati.

Sasraningrat. (1984). Departemen pendidikan dan anak tunanetra. Jakarta: Puspa Swara.

Snyder. (2002). Personal adjustment and mental health. New York: Holt, Rinehart and Winston.

Soemantri, T. S. (2007). Psikologi anak luar biasa. karakteristik dan masalah perkembangan anak tunanetra. Bandung: Refika Aditama

Sulistya, W. K. 2005. Penerimaan diri kompetensi interpersonal. Yogyakarta: Wangsa Manggala.

Sumekar, G. I. (2009). Anak berkebutuhan khusus. Padang: UNP Press.

Taylor. (1995). Health psychology. San Fransisco: McGraw Hill Inc.

Tentama, F. (2010). Berpikir positif dan penerimaan diri pada remaja penyandang cacat tubuh akibat kecelakaan. Humanitas, 6(1), 67-75.

Tentama, F. (2012). Manfaat penerimaan diri bagi difabel. Republika, 69. 
Tentama, F. (2014). Hubungan positive thinking dengan self-acceptance pada difabel (bawaan lahir) di SLB Negeri 3 Yogyakarta. Jurnal Psikologi Integratif, 2(2), $1-7$.

Tobing, F. (2006). Pengembangan kepribadian. Bandung: Remaja Rosda Karya.

Somantri, T. S. (2006). Psikologi anak luar biasa. Bandung: Refika Aditam. 